\title{
Scientific Literacy: A Proposal for Science Teacher Education
}

\author{
Susan Bruna Carneiro Aragão ${ }^{1}$, Maria Eunice Ribeiro Marcondes ${ }^{2}$ \\ Programa de Pós-graduação Interunidades - University of São Paulo ${ }^{1,2}$ \\ Brazil
}

\begin{abstract}
Scientific Literacy (SL) is a term used in many countries to define the purpose of science education. Based on previous research with undergraduate science students [1], an academic discipline in a teacher education program was developed in order to promote prospective teachers' understanding about Scientific Literacy. The academic discipline content consisted of three approaches: ScienceTechnology-Society (STS), Inquiry, and History and Philosophy of Science (HPS). The research objective was investigated how undergraduate science students (future teachers) understand and reflect about the scientific literacy concept. This proposal was applied in a Brazilian Federal University located in the metropolitan area of São Paulo. Twelve students attended seventeen classes. They studied three different methodological approaches: Science, Technology and Society (STS), History and Philosophy of Science (HPS), and Inquiry. Some aspects of Nature of Science were also discussed. The researcher, a PhD student, elaborated levels of comprehension for each approach in order to analyze the results. The primary results so far indicated that some students were able to establish relationships among these approaches and their comprehension of each approach was dependent on the emphasis of the teacher educator.
\end{abstract}

\section{Introduction}

Scientific literacy is a term used in many countries to define the purpose of science teaching. Although there is no consensus on its definition in Portuguese language, it can be identified as an objective in basic education in several national and international science curricula [1].

According to Roberts, there are two ways to define SL, called Vision I and Vision II. Vision I is that advocated by theorists, that SL is the understanding of scientific concepts and processes, of pure scientific knowledge. In contrast, Vision II emphasizes the social aspect, presenting situations to students that involve scientific aspects so that they can develop their citizenship [2].

Millar and Osborne stated that "the primary and explicit aim of the 5-16 science curriculum should be to provide a course which can enhance 'scientific literacy', as this is necessary for all young people growing up in our society, whatever their career aspirations or aptitudes." [3]

In Brazil, more specifically in São Paulo State Curriculum Proposal, SL is mentioned as one of the objectives for basic education in order to prepare students to become active citizens in society. [4]

\section{Levels and Fundamentals of Scientific Literacy}

According to Bybee et al. [5], there are levels of Scientific Literacy (SL).

- Illiteracy: Students who cannot relate to, or respond to a reasonable question about science. They do not have the vocabulary, concepts, contexts, or cognitive capacity to identify the question as scientific.

- Nominal: Students recognize a concept as related to science, but the level of understanding clearly indicates misconceptions.

- Functional: Students can describe a concept correctly but have a limited understanding of it.

- Conceptual and procedural: Students develop some understanding of the major conceptual schemes of a discipline and relate those schemes to their general understanding of science. Procedural abilities and understanding of the processes of scientific inquiry and technological design are also included in this level of literacy.

- Multidimensional: This perspective of scientific literacy incorporates an understanding of science that extends beyond the concepts of scientific 
disciplines and procedures of scientific investigation. It includes philosophical, historical, and social dimensions of science and technology. Here students develop some understanding and appreciation of science and technology regarding its relationship to their daily lives. More specifically, they begin to make connections within scientific disciplines, and between science, technology, and the larger issues challenging society.

Based on Bybee's ideas and on the research developed in the master's degree of one of the authors (SBCA) [1] it is stated the idea that SL can be promoted by teachers for secondary school students when three methodological approaches are applied in science classes. These three approaches are:

- Science, Technology and Society (STS): provides reflection and discussion on different point of views about socioscientific issues, engage in debates, and develop argumentative skills [6].

- $\quad$ History and Philosophy of Science (HPS): provides the development of a constructivist view about Science and the understanding of scientific knowledge as a dynamical, collaborative and non-linear process [7].

- Inquiry: provides reflection on a problem and searching for solutions by formulating hypotheses, organizing information, and elaborating conclusions [8].

Therefore, according to this theoretical background, the research question stated is: how a subject designed by a teacher educator from the perspective of SL provides undergraduate science teachers' understanding and reflections on SL teaching?

The research goals are the following:

- analyze conceptions related to nature of science, STS, HPS and inquiry-based teaching approach hold by undergraduate science teacher students;

- $\quad$ investigate if and which activities proposed by the teacher educator during the discipline provided the undergraduate science teachers' reflecting on their ideas about teaching-learning process and SL concept;

- analyze whether undergraduate science students' have appropriated the concept of SL and its foundations;

- $\quad$ analyze how undergraduate science students applied SL and its fundamentals to lesson plans they were invited to design.
The researcher authors expect that the discipline as it was proposed based on the study and reflection about SL and its three fundamentals can provide means to future science teachers promote SL in secondary science classes. Many authors point to the need to integrate contents to approaches, especially nature of science in science classroom. However, this requires reflective practices in teacher education courses, and activities that lead them to reflect on their own conceptions [9], [10].

Concerning the idea of investigating a teacher education program, we invited a teacher educator to participate in our research. The teacher educator elaborated a course plan for the discipline named "Science Teaching Practice". In this plan, the teacher educator took into account the difficulties faced by students in a similar discipline in 2015, causing her to rethink some activities, reformulating them, with the aim of allowing the students (future teachers) more time for reflection. For instance, one reformulation was students had to write a journal throughout the discipline, in order to promote students' reflection about theory and practice.

Twelve undergraduate science students attended this discipline. One of the researchers attended and participated in all 17 classes. Before each class the teacher educator and this researcher gathered to talk about the previous and the next class. This time of discussion promoted moments of reflection about pedagogical practice in teacher education.

\section{Discussion}

The initial analysis has the aim to relate teacher educator actions to students' conceptions, in order to verify how and what actions allowed students to reflect about SL and its fundamentals that could lead them to advance in their understanding of these concepts. It will also be analyzed the transcriptions of the classes audios, the students' lesson plans, the interviews, and students' journal.

Levels of understanding each approach - STS, HPS, IBT - were developed in order to identified undergraduate science students (future teachers) understanding.

\section{Conclusion}

In this research we intended to investigate how an academic discipline in a teacher education program can influence the conceptions of undergraduate students.

The initial analysis has the aim to relate the actions of the teacher educator to students' conceptions, in order to verify how and what actions allowed students to reflect about SL and its fundamentals that could lead them to advance in their understanding of these concepts. 
It will be analyzed the transcriptions of the classes audios, the undergraduate students' lesson plans, the interviews, and students' journal.

Another analysis that we intend to carry on is concerned to the reformulation from 2015 to 2016. The interviews and the questionnaire answered by the teacher educator will be analyzed in order to verify how her conceptions were modified due to the presence of the researcher in the classes.

\section{References}

[1] S.B.C. Aragão. "Scientific Literacy: prospective teachers' conceptions". Dissertation (Master degree), University of São Paulo. Institute of Education, Institute of Physics, Institute of Chemistry and Institute of Biology, São Paulo, 2014. www.teses.usp.br/teses/disponiveis/ 81/81132/tde-14102015-151323/pt-br.php, (Access Date: 26 September, 2018).

[2] D.A. Roberts, Scientific Literacy/Science Literacy. In S.K. Abell and N. G. Lederman (Eds.), Handbook of Research on Science Education, National Association for Research in Science Teaching, Virginia - USA, 2007.

[3] Millar, R., J. Osborne, Beyond 2000: Science education for the future - The report of a seminar series funded by the Nuffield Foundation, King's College, London - UK, 1998.

[4] São Paulo (Estado) Secretaria da Educação. Currículo do Estado de São Paulo: Linguagens, códigos e suas tecnologias, Secretaria da Educação, São Paulo, 2011.

[5] Bybee, R.W., J. C. Powell; L. W. Trowbridge, Teaching Secondary School Science, Pearson Merril Prentice Hall, Ohio - USA, 2004.

[6] G.S. Aikenhead, "Research into STS Science Education". Revista Brasileira de Pesquisa em Educação em Ciências, ABRAPEC, São Paulo - Brazil, 2009, pp. 121.https://seer.ufmg.br/index.php/rbpec/article/view/2204/ 1604, (Access Date: 26 September, 2018).

[7] Allchin, D., Teaching Nature of Science: perspectives and resources, Ships Education Press, Minnesota - USA, 2013.

[8] D. Hodson, "Experiments in science and science teaching", Journal of Educational Philosophy and Theory, Taylor and Francis Group, London, 1988, pp. 53-66. https://doi.org/10.1111/j.1469-5812.1988.tb00144.x, (Access Date: 26 September, 2018).

[9] R.M. Vieira, I.P. Martins, "Formação de professores principiantes do ensino básico: suas concepções sobre ciência-tecnologia-sociedade", Revista Iberoamericana CTS, Consejo Nacional de Investigaciones Científicas y Técnicas, Buenos Aires - ARG, 2005, pp. 101-121. www.revistacts.net/files/Volumen\%202\%20-\%20Número \%206/doss03.pdf, (Access Date: 26 September, 2018).
[10] D.A. Schön. Educating the Reflective Practitioner: Toward a New Design for Teaching and Learning in the Professions. San Francisco, Jossey-Bass, 1990. 